\title{
Assessment of the Organizational Structure of the Ethnographic Museum Cairo, Egypt. \\ Mahrous Elsanadidy,
} Ph.D. Researcher at the Helwan University, Cairo, Egypt. elsanadidy@gmail.com

\begin{abstract}
:
The Ethnographic museum Cairo is the oldest and most significant Ethnographic museums in Egypt and the Arab world. It contains thousands of unique objects and artefacts collected from African countries, historic Cairo, Egyptian cities and villages. But, it has neither a simple organizational structure nor professional staff that can manage its museum activities and services such as collections, technical operation, Human resources, investment, and visitor services management in an effective and efficient way.

Hence the researcher tries to assess management of the Ethnographic museum and its current organizational structure in order to set out proposals for the best practices and most effective organizational structures applied in museums around the world to be applied in it through research methodologies based on a theoretical, applied study, SWOT analysis of the Ethnographic museum management, analyzing questionnaires, and interviews with museum experts and professionals around all the world related to organizational structures.
\end{abstract}

Key words: Organization, Organizational structure, Museums, Ethnographic Museum Cairo.

\section{Introduction:}

Museums have been currently developing very fast especially; we live in the digitalization age, social media, diverse multimedia and artificial intelligence. As, they have not only become organizations that acquire, preserve, conserve, study and exhibit objects and artefacts as known in the past, but also, they have been offering a lot of activities and services and producing goods that customers want at competitive prices (Armstrong, 2012, pp. 11-13). According to the last museum definition adopted by the 22nd General Assembly of the international council of museums (ICOM) in Vienna, Austria, on 24 August 2007 is as follows "A museum is a nonprofit, permanent institution in the service of society and its development, open to the 
public, which acquires, conserves, researches, communicates and exhibits the tangible and intangible heritage of humanity and its environment for the purposes of education, study and enjoyment (Museum Definition, International Council of Museum). In order to achieve all of these missions, and purposes in effectively and efficiently; they should have certain goals, a proper planning, a deliberated organizational structure (Al-Khateeb, 2002, p. 113) and coordinated activity systems linked to the contexture (Armstrong, 2012, pp. 11-13), and control (Al-Khateeb, 2002, p. 113). Regarding to an organizational structure is known as a system of communication, authority, status, rewards, and workflow, as it describes the internal characteristics of an organization. They create a basis for measuring and comparing organizations. This organizational structure usually influences in its shape with Contextual dimensions characterize the whole organization, including its size, work processes, technology, environment, and goals (Al-Khateeb, 2002, p. 75). They describe the organizational setting that influences and shapes the structural dimensions. To understand and evaluate organizations, one must examine both structural and contextual dimensions. These dimensions of organization design interact with one another and can be modified to accomplish the purposes. An organization structure involves two basic elements. the First element is procedures and the second one is organizational relationships. As for procedures, include essential activities and tasks, personnel, resources, workplace, and communications between departments, sections, units, professionals and resources to achieve organization goals. As for the organizational relationships, they contain formal and informal types. A formal type is functional behaviours rules, goals and policies of an organization that are usually written in the shape of decrees, regulations and resolutions seeking to fulfil the setting goals, but, informal type is the social relations among co-workers that are not often written but, they appear in their joint friendly, understanding relations. Al-Kateeb says that the ideal, effective organizational structure that has defining, clear goals and matches between formal and informal relations (Al-Khateeb, 2002, pp. 113-115).

\section{The organizational structure of the Ethnographic museum:}

The Ethnographic museum is a part of activities of the Geographical Society of Egypt that established in 1875 ( Emmanuelle, 2015) at the reign of Khedive Ismael (1863-1879) (Alayoubi, 
2016). The Geographical Society of Egypt was a non-Governmental organization (the Geographical Society of Egypt; International Council on Archive) established the Ethnographic museum that opened for the public in 1895. It located within a building of the Geographical Society of Egypt next to the Egyptian Parliament building at El-Qasr El-Eini Street near the Tahrir square in Cairo (hosny, 2019, pp. 1-2). It is considered one of the most important and interesting ethnographic museums in Egypt and the Arab world because it contains unique, priceless collections acquired from African countries, in particularly, the countries of the Nile pool such as Sudan, Ethiopia, Rwanda, Burundi, Uganda.., historic Cairo and Egyptian cities and Countryside (Guide book to the Ethnographic museum; the Geographic Societyof Egypt, 1976, p. 4). They are narrating significant customs and traditions about Egypt and African countries of the Nile river pool between the 18 th century and the early 20 th century.

\section{The aims and objectives behind establishing this museum were to:}

1- Protect and preserve Egyptian and African Heritage that was about to disappear due to many reasons such as; Rapid development of the life styles patterns, their aspects, and tools at the end of 19th century and beginning of the 20th century and rapid changing in customs and traditions related to clothes, jewellery, professions, living tools, crafts and their techniques, celebrations and their process, agriculture tools, hunting and war weapons.

2- Complete the comprehensive image of Egyptian civilization that has Pharoanic, GrecoRoman, Islamic and Coptic treasures exhibited in Egyptian museums, Greco-Roman museum, Islamic art museum, and Coptic museum (Guide book to the Ethnographic museum; the Geographic Societyof Egypt, 1976, p. 4).

3- Benefit scholars, and succeeding generations for study and research.

4- Be as resource of avenues for the Geographical society of Egypt that supports its activities works (http://www.egyptiangs.com).

\section{Development of the Ethnographic Museum collections:}

Collections of the Ethnographic museum were acquired by many methods including objects and artefacts collected by the Geographic exploration expeditions to Africa, objects and artefacts granted, or gifted by foreign and Egyptian societies (hosny, 2019, p. 9), travellers or friends of 
the society (Guide book to the Ethnographic museum; the Geographic Societyof Egypt, 1976, pp. 6-7), Ministry of Education, and the Suez canal authority (Guide book to the Ethnographic museum; the Geographic Societyof Egypt, 1976, pp. 6-7) and others by purchasing as following: One of most significant collections is the African ethnographic collection gifted in 1889 by Lieutenant General Mukhtar Pasha, Egypt's Armed Forces Chief of Staff.

In 1928, the society bought many objects and artifacts representing the lives in rural communities and Cairo's people, and received a lot of gifts and presents (hosny, 2019, p. 20). In 1930, the Suez Canal Authority gifted it a significant collection of photos, maps, and models representing digging works of the Suez Canal and building works of the Suez Canal cities (Guide book to the Ethnographic museum; the Geographic Societyof Egypt, 1976, p. 13), (hosny, 2019, p. 21).

\section{Exhibition halls:}

The first core hall of the Ethnographic museum was opened in 1895, and then others halls succeeded after increasing numbers of its collections through collection, grant, gifts or purchasing. In 1924, the head of the Geographical society of Egypt assigned the English researcher of the society for African affairs Mr. Tomas to document, study and re-exhibit its collections which reached 516 objects, in a scientific, thematic method (Guide book to the Ethnographic museum; the Geographic Societyof Egypt, 1976, p. 6). The Ethnographic Museum now has six thematic exhibition halls circulating as following (Fig.1):

The first hall is a Cairo's hall(Fig.2) that narrates the customs and traditions of Cairo's people during the 18th, 19th, and the early 20th centuries through displaying original objects, replicas, dioramas, portraits, models including the carrying- chair (Mahmal) of the Kaa'ba cover( Fig.2), a collection of smoking tools, of jewellery and accessories, of cosmetics and barber's tools, of washing and bathing vessels, of musical instruments, of light means and firing tools (lamps, candlesticks, lanterns, lighter), of manuscripts and Arabic calligraphy tablets, of drawings of traditional café, of traditional clothes and textiles and of traditional weapons and sticks (Guide book to the Ethnographic museum; the Geographic Societyof Egypt, 1976, pp. 8.10-23).

The second hall is about Cairo traditional crafts displaying collections of metal works of copper and iron, of glass works of mosque lamps, of house services like ironing clothes, sharpening 
knives, quizzing cane juice, grinding mortars, of leatherworks of shoes, bags,..., woodworks of carpentry tools and joinery wood-like Oriel windows (Mashrabiah), curtains, doors, of handmade textiles works of spinning, weaving tools (Guide book to the Ethnographic museum; the Geographic Societyof Egypt, 1976, pp. 8, 24-31) .

The third hall is named the oriental hall that displays collections of Arabesque furniture with inlaying of ivory and mother of pearls, of glass plaster windows, of tent-making tools and pieces of tents (Guide book to the Ethnographic museum; the Geographic Societyof Egypt, 1976, pp. 8, 32-37).

The fourth hall narrates the Egyptian countryside through displaying set of weights and water and grains measurement tools, collections of pottery vessels for drinking, palm loaves baskets craft, peasant's tools, such as sickles, winnowing machine "Nourage" (Fig. 2), of female and male peasants' clothes, and villagers games (Guide book to the Ethnographic museum; the Geographic Societyof Egypt, 1976, pp. 8, 38-42).

The fifth hall is about an Africa heritage displaying a collection of weapons like swords, daggers shields, spears, fire rifles.., of musical instruments like drums, bells, traditional furniture, traditional clothes, jewellery and ornaments, coins, dolls (Guide book to the Ethnographic museum; the Geographic Societyof Egypt, 1976, pp. 8, 45-52) (Fig. 2).

The sixth hall narrates the Suez Canal project by displaying a collection of documents, maps, photos of digging, and dioramas of inaugurating the Suez Canal (Guide book to the Ethnographic museum; the Geographic Societyof Egypt, 1976, pp. 8, 53-6).

\section{Management systems in the Ethnographic Museum:}

\section{The strengths of a museum:}

The museum contains unique, diverse objects and artefacts that serve several values about the African, Cairo and Egyptian countryside's tangible and intangible heritage. These values are such as: historical, cultural, social, economic, study and research, scientific and educational, fun and entertainment, and community engagement. The Ethnographic museum is a part of the 
geographic society that has valued library with rare books, journals, and periodicals (http://www.egyptiangs.com).

Furthermore, the location of the museum is a distinguished location in Cairo down town, so it is easy to reach it by all means of transportation such metro, Taxi, and public transportation.

\section{The weaknesses of the Ethnographic museum:}

The Ethnographic museum faces several challenges and obstacles that stand barriers in front it to achieve its objectives, missions and message as follows:

1- Funding: The museum is part of the activities of the Geographical Society of Egypt, which is a NGO society with limited resources (News of the Geographical Society of Egypt), while its activities need additional resources in order to carry out its various activities efficiently, especially the museum works.

2- Display: The museum needs to re-display its acquisitions in modern means of exhibitions and explanation, such as showcases, lighting systems, air conditioning, Labels, panels, graphics and animation, interactive screens, mobile applications, and documentaries films.

3- Documentation: The museum needs to register and document its objects and artefacts in digital and modern multimedia methods, as well as traditional paper-based documentation, because there are no register books or documentation of the museum's objects and artefacts until they can be inventoried and protected from theft and looting and repatriated them in case of theft.

4- Conservation: The museum needs conservation laboratories and specialists in restoring and conservation its possessions of all kinds and materials.

5- Proper storage: The museum needs appropriate magazines to keep the items not displayed in a suitable environment and secured by modern means against the disaster of theft or fire.

6- Publication: The museum needs a scientific publication of its holdings, whether in catalogues, books or brochures.

7- Promotion: The museum needs a website and social media accounts to introduce visitors to this museum, its collections, goals, mission and educational activities.

8- Efficient management: The museum needs strategic planning and governance defining its goals, mission and organizational structure to implement this through the recruiting of 
specialized staff in each field, as the museum is currently managed by the board of directors of Geographic society of Egypt consisted of fifteen members (the Geographical Society of Egypt; International Council on Archive) but it has not among them museum experts or professionals. The museum is managed by only few employees who are unqualified and on retired1. So the museum cannot practice its missions in an efficient and effective way such as accountability of objects, security, conservation, study and research, refurbish exhibition...The museum needs several departments specified roles and responsibilities, such as a security, Human resources, financial and administrative affairs, operation affairs, and engineering and maintenance department. As well, It has not a lot of facilities like, ticketing, information desk, visitors services, educational programs, disable accessibilities.

9- Location: In spite of the location of the museum is very good in the down town of Cairo, but it now became a weak point because it exists within the parliament buildings zone where audiences could face difficulties to enter it easily because they should submit to strict security procedures.

\section{Discussion:}

the Ethnographic museum exhibits unique amazing collections of the heritage of African countries, in particularly, the countries of the Nile pool such as Sudan, Ethiopia, .., historic Cairo and Egyptian cities and Countryside that bear significant values;

\begin{tabular}{|l|l|c|}
\hline values & \multicolumn{1}{|c|}{ attributes } & $\begin{array}{l}\text { Score of authenticity, } \\
\text { integrity, sustainability } \\
\text { and uniqueness(1-low }, \\
2 \text {-medium, 3-high) }\end{array}$ \\
\hline Historical & $\begin{array}{l}\text {-Its building is antiquities building } \\
- \text { Objects and artefacts from } 18^{\text {th }} \text { century to early } 20^{\text {th }} \\
\text { century. }\end{array}$ & 3 \\
\hline Social & $-\quad$ Objects and artefacts tell us some tales of customs & \\
\hline
\end{tabular}

${ }^{1}$ Interview with Mr Ahmed Mekkawi has been working as the director of the Ethnographic museum since 1970 till now. 
INTERNATIONAL JOURNAL OF

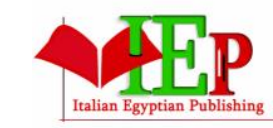

MULTIDISCIPLINARY STUDIES ON MANAGEMENT, BUSINESS, AND

ECONOMY

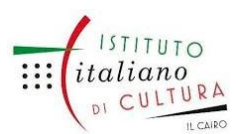

ISSN: 2735-5446

VOLUME 2, ISSUE 2, 2019, 1- 15.

www.egyptfuture.org/ojs/

\begin{tabular}{|l|l|c|}
\hline & $\begin{array}{l}\text { and traditions in African countries and Egypt, function, and } \\
\text { usages in societies }\end{array}$ & \\
\hline Cultural & $\begin{array}{l}\text { Objects and artefacts bears diverse cultures in different } \\
\text { places in certain times }\end{array}$ & 3 \\
\hline Economic & - Objects and artefacts are priceless. & \\
& - It is a resource of national income and important touristic \\
destination. & \\
& - It is an element for sustainable development. & \\
\hline $\begin{array}{l}\text { Educational\& } \\
\text { Scientific }\end{array}$ & - Objects and artefacts are educational means for students \\
and researchers & \\
\hline Fun & Objects and artefacts are fun, enjoyment and mediation for & \\
\hline
\end{tabular}

So the Ethnographic museum needs an organizational structure to implement objectives, mission, and message as follows:

1- Funding: through creating National and international fundraising campaigns to collect kind and unkind support to help it begin as soon as possible to save these unique collections before losing them by any emergent accident or fires as it happened several times near it such as fires which burnt the buildings of the parliament and the scientific assembly during unrest times of 2011's upraising.

2- Documentation: The museum needs to register and document its objects and artefacts in digital and modern multimedia methods, as well as traditional paper-based documentation, until they can be inventoried and protected from theft and looting and repatriated them in case of theft.

3- Display: The museum will be re-displayed its objects in modern methods of exhibitions and interpretation through new showcases, lighting systems, air conditioning, Labels, panels, graphics and animation, interactive screens, mobile applications, and documentaries films to show their values. 
4- Conservation: The museum will establish conservation laboratories and specialists in restoring and conservation its possessions of all kinds and materials.

5- Proper storage: The museum will organize its objects to keep the items not displayed in a suitable environment and secured by modern means against the disasters of theft or fire.

6- Publication: The museum will do scientific publications of its acquisitions, whether in catalogues, books or brochures.

7- Promotion: The museum will create a website and social media accounts to introduce visitors to this museum, its collections, goals, mission and educational activities.

8- Efficient management: The museum will set strategic plans and governance laws defining its goals, mission and clear organizational structure to implement this through the recruiting of specialized staff in each field. As the museum will be managed by the board of directors of Geographic society of Egypt consisted of fifteen members (the Geographical Society of Egypt; International Council on Archive) but it will join them museum experts or professionals. The museum will be managed by all museum specialists qualified and trained. In order that the museum practice its missions in an efficient and effective way such as accountability of objects, security, conservation, study and research, refurbish exhibition...The museum needs several departments specified roles and responsibilities, such as a security, Human resources, financial and administrative affairs, operation affairs, and engineering and maintenance department. As well, it will provide with new facilities like, ticketing, information desk, visitors services, educational programs, and disable accessibilities.

9- Location: the researcher thinks when the building of the Egyptian parliament assemblies will move to the new administrative Capital help this museum revive again and its location will be new value of its values because it is located in the down town of Cairo, but it now became a weak point because it exists within the parliament buildings zone where audiences could face difficulties to enter it easily because they should submit to strict security procedures.

Finally the researcher suggests a simple horizontal organizational structure (look at the organizational chart proposed for the Ethnographic Museum fig.3) based on: goals oriented flexibility, and effective communication; reducing supervising jobs, and hiring few numbers of employees of high skills with multifunction; contracting relation; using outsources suppliers in 
INTERNATIONAL JOURNAL OF

MULTIDISCIPLINARY STUDIES ON MANAGEMENT, BUSINESS, AND

ECONOMY

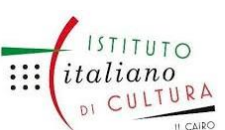

www.egyptfuture.org/ojs/

particularly, in case of small museums like the ethnographic museum. As well the museum should care talent employees and creating suitable workplace. 


\section{References}

- Emmanuelle, P. (2015). Le musée d'Ethnographie de la Société de Géographie d'Égypte.

- Griffin, D. (n.d.). Organizational Structure \& Its Functions. Retrieved May 5, 2020, from https://smallbusiness.chron.com/organizational-structure-its-functions-3722.html

- $\quad$ Langer , J., \& LeRoux, K. (2017, March 31). Developmental Culture and Effectiveness in Nonprofit Organizations. Public Performance \& Management Review, 487.

- $\quad$ Root III, G. N. (n.d.). Strategies to Overcome the Traditional Organizational Structure. RetrievedMay7,2021,fromhttps://smallbusiness.chron.com: https://smallbusiness.chron.com/strategies-overcome-traditional-organizational-structure4899.html

- Skripak, S. J. (2016). Fundamentals of Business. In S. J. Skripak. the United States of America: VT Publishing.

- Guide book to the Ethnographic museum; the Geographic Societyof Egypt. (1976). Cairo: the Geographic Societyof Egypt.

- Alayoubi, A.-y. (1923). Egypt's history in the reign of Khedive Ismail Pasha, Cairo, Egypt.

- Al-Khateeb, M. A. (2002). Human resources management; Manpower management in Globalisation and e-Economy. Cairo, Egypt: Israa press.

- Armstrong, R. L. (2012). Organizational Theory and Design. Nelson Education.

- Bass, B. (n.d.). The Traditional Hierarchy Business Model. Retrieved May 7, 2021, from https://smallbusiness.chron.com: https://smallbusiness.chron.com/kinds-managementorganizations-20207.html

- Daft, R. L. (2010). Organization Theoryand Design. Mason, USA: South-Western, Cengage Learning.

- database, T. E. (n.d.). http://egyptological.com/looting. Retrieved february 20, 2018, from http://egyptological.com/looting

- Davoren, J. (n.d.). Kinds of Management Organizations. Retrieved May 7, 2021, from https://smallbusiness.chron.com: https://smallbusiness.chron.com/kinds-managementorganizations-20207.html

- Deshpande, R. (1989). Organizational Culture and Marketing:Defining the research agenda. American Marketing Association, 53(1), 3-15.

- Duggan, T. (n.d.). How Does Organizational Structure Affect Performance Measurement? Retrieved May 7, 2021, from https://smallbusiness.chron.com: https://smallbusiness.chron.com/organizational-structure-affect-performancemeasurement-78846.html

- Duggan, T. (n.d.). Successful Organizational Structure. Retrieved May 7, 2021, from https://smallbusiness.chron.com: https://smallbusiness.chron.com/successfulorganizational-structure-58347.html

- Griffin, D. (n.d.). Retrieved May 7, 2021, from https://smallbusiness.chron.com: https://smallbusiness.chron.com/explanation-organizational-structure-282.html 
- GRIFFIN, D. J. (1987). Managing in the Museum Organization. The International Journalof Museum Management and Curatorship, 387-398.

- Griffin, D. J, \& Abraham, M. (2000, July 30). The Effective Management of Museums: Cohesive Leadership and Visitor-Focused Public Programming. Museum management and Curatorship, 18(4).

- Harris, J. (2011). Dialogism and the visitor experience, in: Dialogic museum and the visitor experience. Taipei, and Kaohsiung.

- Hill, B. (n.d.). How to Successfully Implement Organizational Structure Into an Organization. Retrieved May 7, 2021, from https://smallbusiness.chron.com: https://smallbusiness.chron.com/successfully-implement-organizational-structureorganization-60062.html

- Hill, B. (n.d.). The Importance of the Organizational Structure for a Company. Retrieved May 7, 2021, from https://smallbusiness.chron.com: https://smallbusiness.chron.com/importance-organizational-structure-company25983.html

- Hosny, H. (2019, Feb 16). The Geographic Sovirety of Egypt(1875-1953); Historical study. Retrieved Feb 20, 2020, from https://www.researchgate.net: https://www.researchgate.net/publication/331154830

- Huebsch, R. ( 2018, October 16). Traditional Hierarchical Organizational Structure. Retrieved May 7, 2021, from https://smallbusiness.chron.com: https://smallbusiness.chron.com/traditional-hierarchical-organizational-structure26174.html

- Hunt, J. (n.d.). The Advantages \& Disadvantages of a Mixed Model Approach. Retrieved May 7, 2021, from https://smallbusiness.chron.com: https://smallbusiness.chron.com/types-team-project-organization-46812.html

- Johnson, S. (n.d.). Vertical Management Structure. Retrieved May 7, 2021, from https://smallbusiness.chron.com: https://smallbusiness.chron.com/vertical-managementstructure-61783.html

- Johnston, K. (n.d.). Five Approaches to Organizational Design. Retrieved May 7, 2021, from https://smallbusiness.chron.com: https://smallbusiness.chron.com/five-approachesorganizational-design-61377.html

- Latham, A. (n.d.). How to Select an Employee Structure for an Organization. Retrieved May 7, 2021, from https://smallbusiness.chron.com: https://smallbusiness.chron.com/select-employee-structure-organization-10017.html

- Leonard, K. (2018, December 12). Organic Structure of Organizational Design. Retrieved May 7, 2021, from https://smallbusiness.chron.com: https://smallbusiness.chron.com/organic-structure-organizational-design-58657.html

- Leonard, K. (2019, February 12). Open System Organizational Structure. Retrieved MAy 8, 2021, from https://smallbusiness.chron.com: https://smallbusiness.chron.com/opensystem-organizational-structure-432.html

- Lewis, J. (n.d.). Formal Vs. Flexible Business Structures. Retrieved May 7, 2021, from https://smallbusiness.chron.com: https://smallbusiness.chron.com/formal-vs-flexiblebusiness-structures-33491.html 
- Linton, I. (n.d.). Business Organizational Structure Examples. Retrieved May 5, 2020, from https://smallbusiness.chron.com: https://smallbusiness.chron.com/businessorganizational-structure-examples-20580.html

- Markgraf, B. (n.d.). Hierarchical Structure Used in a Modern Organization. Retrieved May 5, 2020, from https://smallbusiness.chron.com: https://smallbusiness.chron.com/hierarchical-structure-used-modern-organization69019.html

- Markgraf, B. (n.d.). Presentation on Organizational Structure. Retrieved May 8, 2021, from https://smallbusiness.chron.com: https://smallbusiness.chron.com/presentationorganizational-structure-63139.html

- Markgraf, B. (n.d.). Tradtional Organizational Structure. Retrieved May 8, 2021, from https://smallbusiness.chron.com: https://smallbusiness.chron.com/tradtionalorganizational-structure-59964.html

- Milano, S. (n.d.). Organization Management \& Development. Retrieved May 7, 2021, from https://smallbusiness.chron.com: https://smallbusiness.chron.com/organizationmanagement-development-65762.html

- Milano, S. (n.d.). The Number of Layers in the Organizational Structure. Retrieved May 7, 2021, from https://smallbusiness.chron.com/number-layers-organizational-structure62820.html

- Milano, S. (n.d.). Types of Organizational Structure in Office Administration. Retrieved May 7, 2021, from https://smallbusiness.chron.com: https://smallbusiness.chron.com/types-organizational-structure-office-administration47132.html

- Morgan, G. (2007). Images of Organizations. Sage Publications.

- Morris , B. L. (1995, june). The growth of museum collections. pp. 10-11.

- Murray, L. J. (n.d.). Definition of an Organization Chart. Retrieved May 7, 2021, from https://smallbusiness.chron.com: https://smallbusiness.chron.com/definitionorganization-chart-2698.html

- Murray, L. J. (n.d.). Introduction to Organizational Structure. Retrieved May 5, 2020, from https://smallbusiness.chron.com: https://smallbusiness.chron.com/businessorganizational-structure-examples-20580.html

- Museum Definition. (n.d.). Retrieved May 30, 2021, from https://icom.museum: https://icom.museum/en/resources/standards-guidelines/museum-definition/

- news of the Geographical Society of Egypt. (n.d.). Retrieved from http://egyptiangs.com: http://egyptiangs.com/

- Organizational-charts. (n.d.). Retrieved Julu 27, 2018, from https://www.lucidchart.com/pages/organizational-charts

- Prajapati, S. (2012). Managing from the middle. In G. Stevens, \& w. Luke (Eds.), A life in museums; managing your museum career. Washington: AAM press.

- Quain, S. (2018, October 19). Traditional Vs. Contemporary Organizational Structure. Retrieved May 7, 2021, from https://smallbusiness.chron.com: https://smallbusiness.chron.com/traditional-vs-contemporary-organizational-structure60243.html 
- Quain, S. (2019, February 12). Basic Types of Organizational Structure: Formal \& Informal. Retrieved May 7, 2021, from https://smallbusiness.chron.com: https://smallbusiness.chron.com/basic-types-organizational-structure-formal-informal982.html

- Quain, S. (2019, March 04). Examples of Closed Systems in Organizations. Retrieved May 8, 2021, from https://smallbusiness.chron.com: https://smallbusiness.chron.com/examples-closed-systems-organizations-15281.html

- Quain, S. (2019, February 6). Tall Organizational Structure. Retrieved from https://smallbusiness.chron.com: https://smallbusiness.chron.com/tall-organizationalstructure-3835.html

- Quain, S. (2019, February 1). The Difference Between Tall \& Flat Organizational Structure. Retrieved May 7, 2021, from https://smallbusiness.chron.com: https://smallbusiness.chron.com/difference-between-tall-flat-organizational-structure23345.html

- $\quad$ Reid, D. M. (1993, Autumn). The Egyptian Geographical Society: From Foreign Laymen's Society to Indigenous Professional Association. (C. P. I, Ed.) JSTOR, Vol. 14(No. 3), 539-572 .

- Richards, L. (n.d.). Organizational Structure for a Manager Supervisor. Retrieved from https://smallbusiness.chron.com: https://smallbusiness.chron.com/hierarchical-structureused-modern-organization-69019.html

- Shamsidar, A. M. (2013). Museum Learning: Using research as best practice in creating future museum exhibition.

- Skripak, S. J. (2016). Fundamentals of Business. Pamplin College of Business and Virginia Tech Libraries.

- Smyth, D. (2020, October 20). The Difference Between a Functional Vs. a Business Process Orientation. Retrieved May 5, 2020, from https://smallbusiness.chron.com: https://smallbusiness.chron.com/organizational-structure-its-functions-3722.html

- the Geographical Society of Egypt. (n.d.). Retrieved may 20, 2019, from http://www.standards-ica.com: http://www.standards-ica.com/view_dist_des.php?id=10

- Woodruff, J. (2018, December 14). Describe Each of the Three Major Types of Organizational Structure. Retrieved May 8, 2021, from https://smallbusiness.chron.com: https://smallbusiness.chron.com/describe-three-major-types-organizational-structure10765.html

- Writing, A. (2019, February 12). Different Types of Organizational Structure. Retrieved May 8, 2021, from https://smallbusiness.chron.com: https://smallbusiness.chron.com/different-types-organizational-structure-723.html 


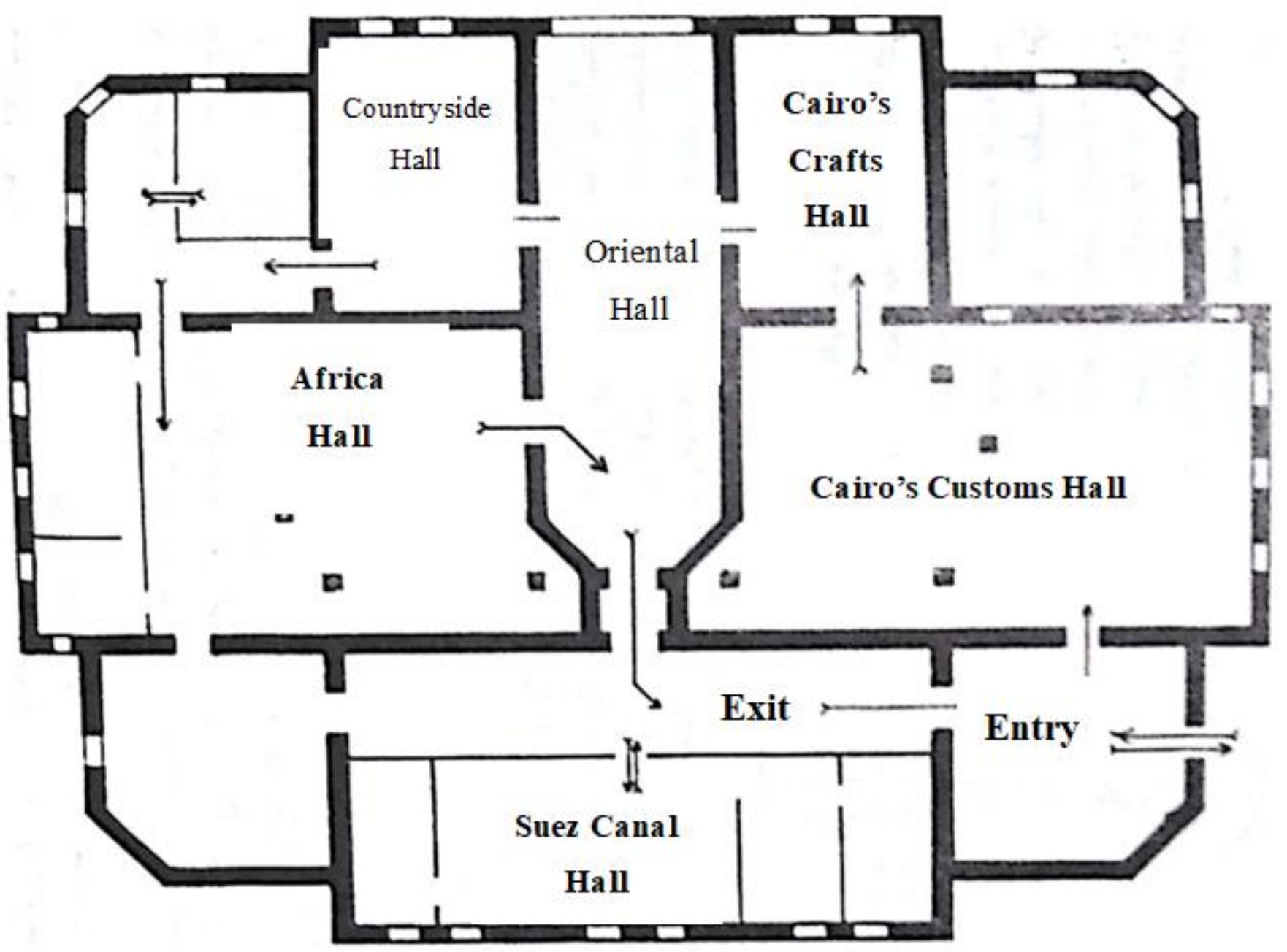

Fig. 1 Ethnographic museum plan, (Guide book to the Ethnographic museum; the Geographic Societyof Egypt, 1976, p. 9) 
INTERNATIONAL JOURNAL OF

MULTIDISCIPLINARY STUDIES ON MANAGEMENT, BUSINESS, AND ECONOMY 
INTERNATIONAL JOURNAL OF

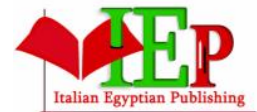

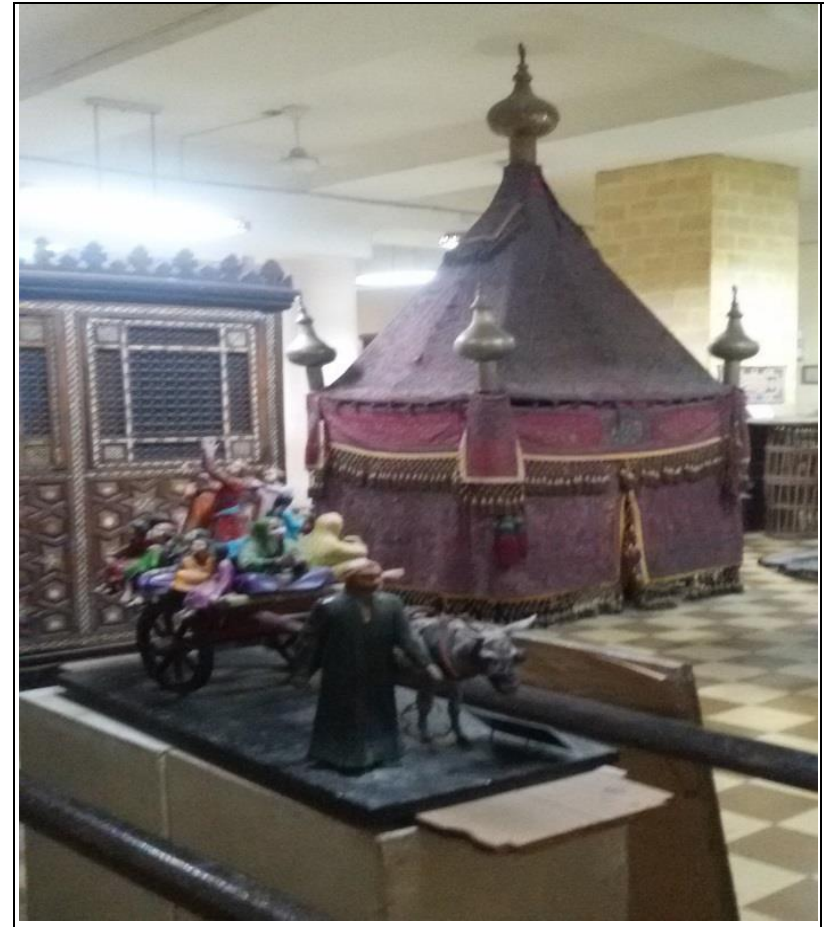

Fig.2.a An image shows a villager with a cart and carrying- chair of Kaaba cover

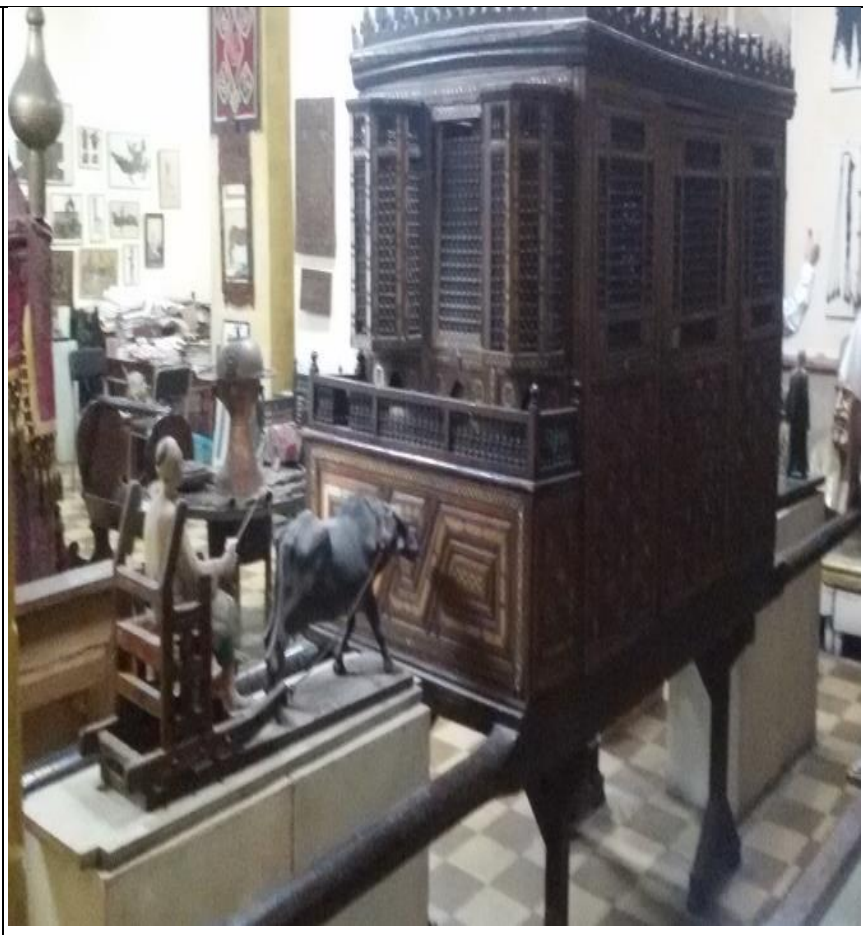

Fig.2b. An image shows Nourage harvest machine, and wedding carrying chair

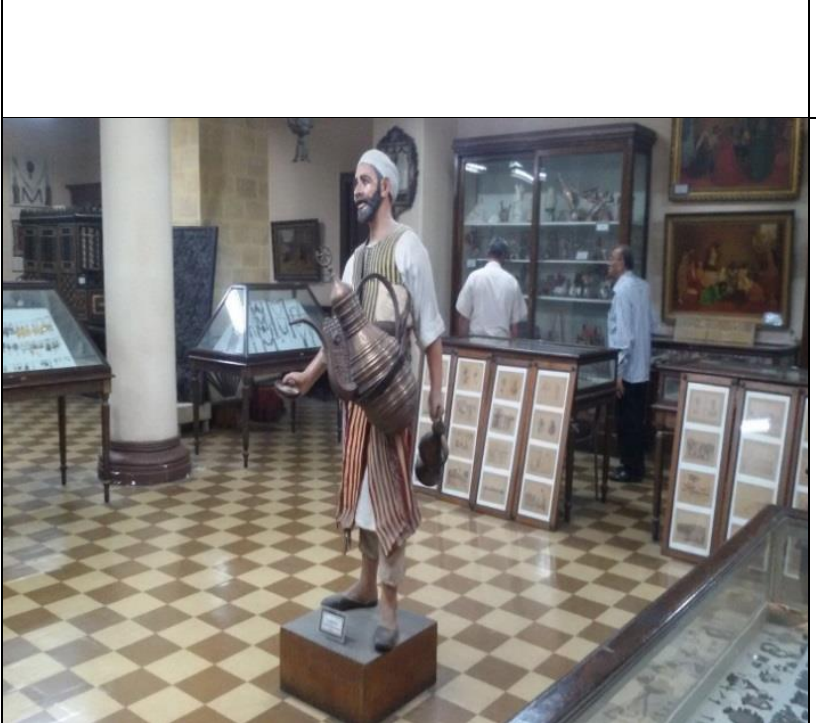

Fig.2c. An image shows Liquorice drink seller

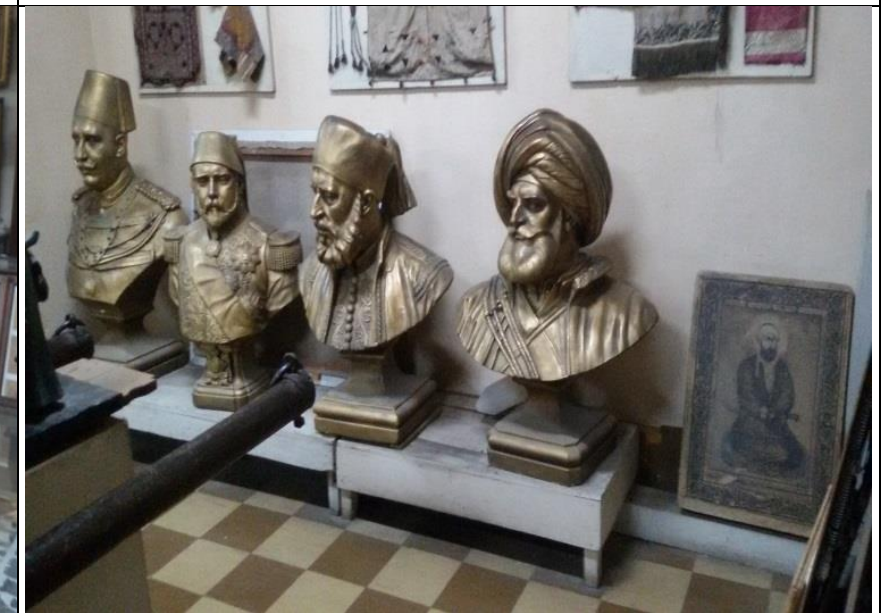

Fig.2.d An image shows four bronze busts of Egypt rulers Mohammed Ali, Ibrahim, Ismael and Fouad

Fig. 2 objects displaying Cairo hall. 
INTERNATIONAL JOURNAL OF

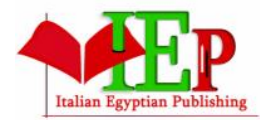

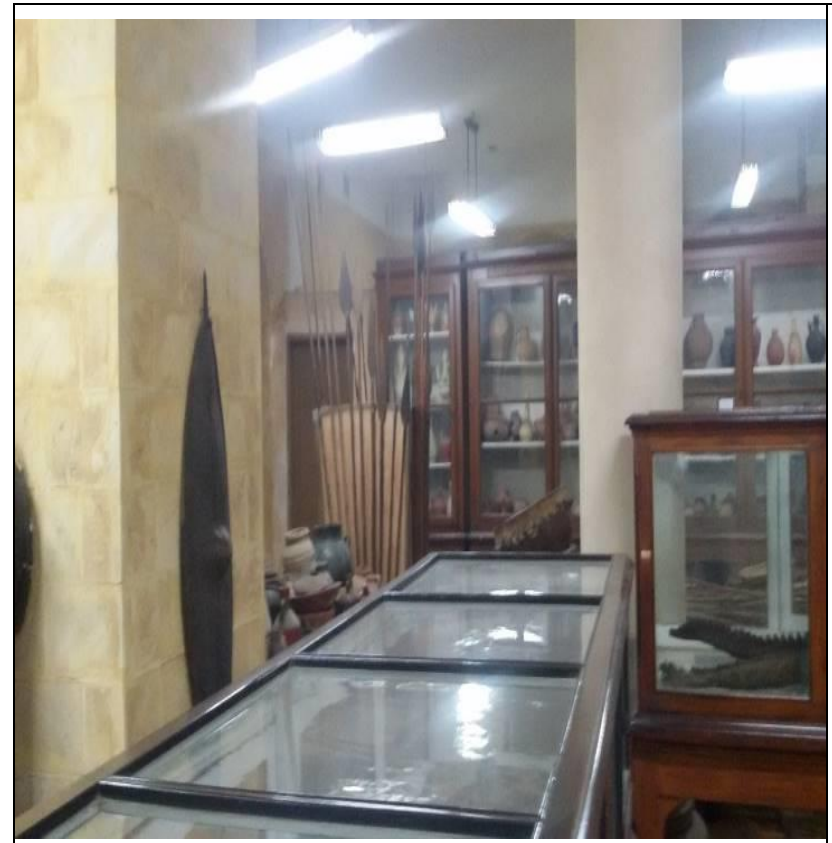

Fig. 3a An image shows African arrows

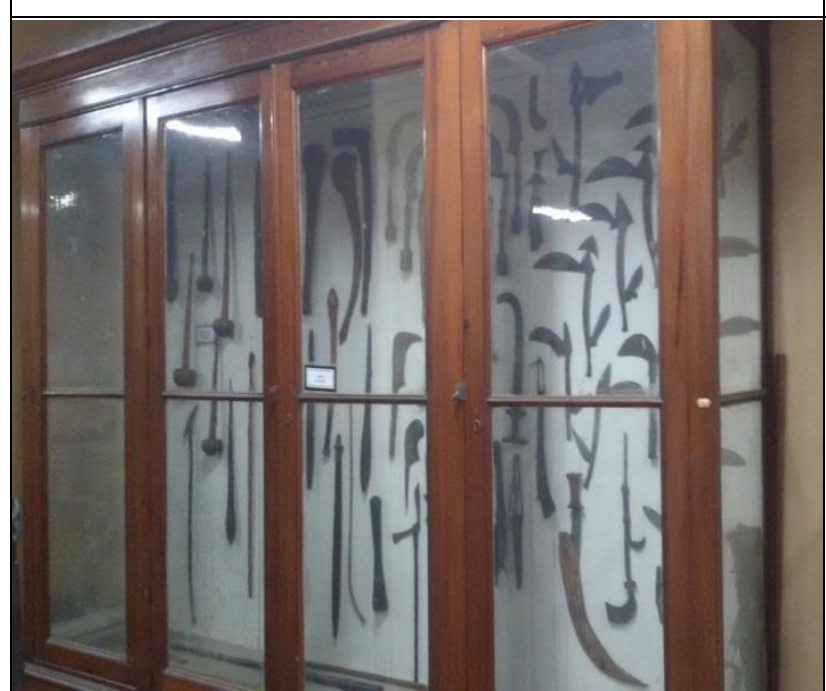

Fig.3c An image shows African weapons

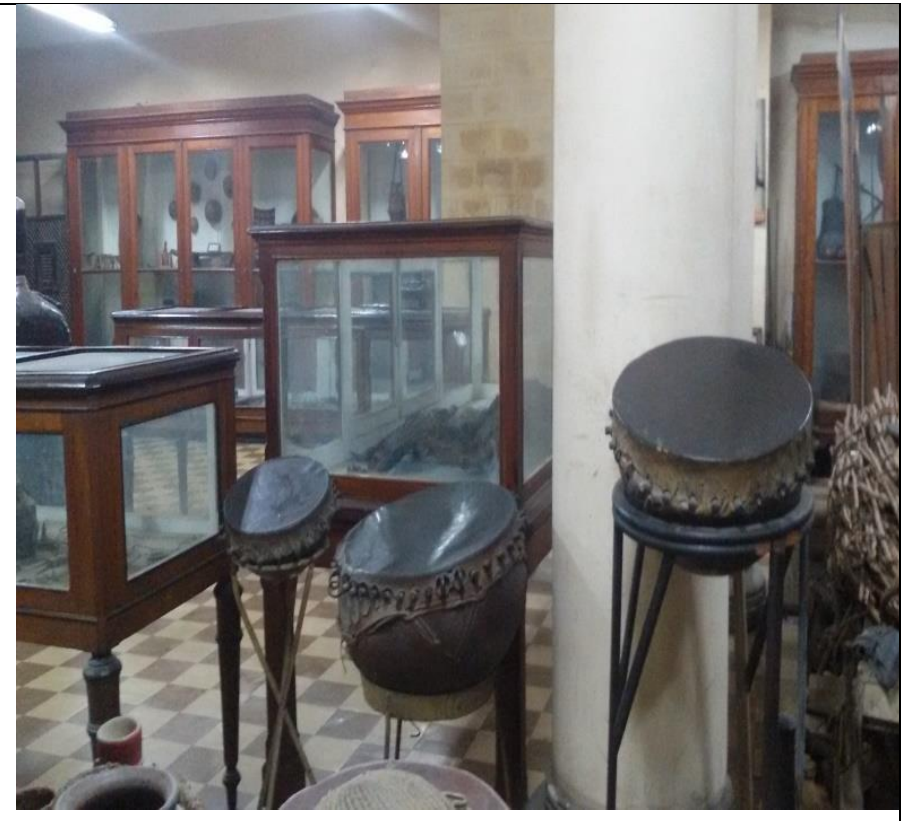

Fig. 3b An image shows African drums

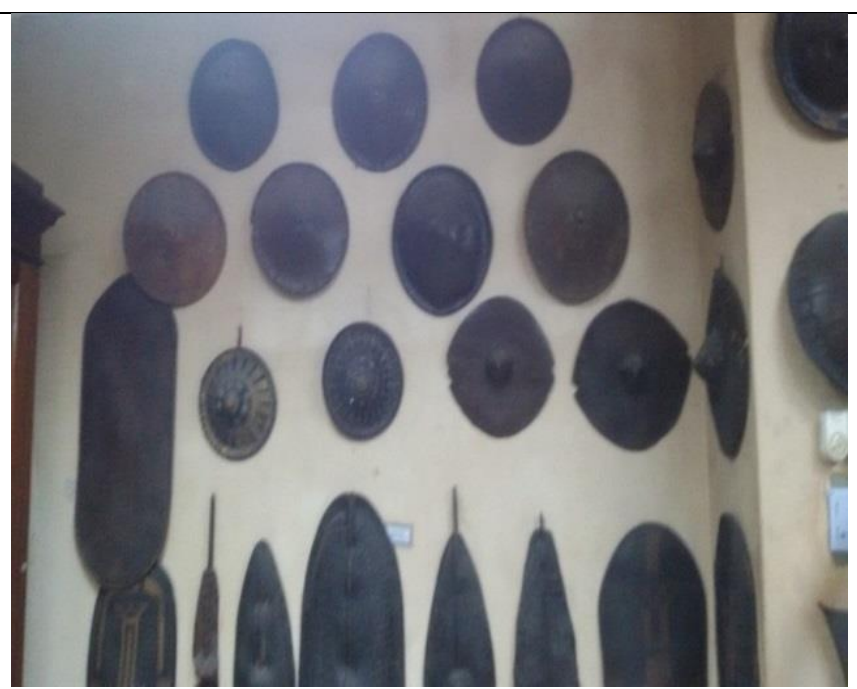

Fig.3d An image shows African shields

Fig. 3 Objects displaying African's hall 
INTERNATIONAL JOURNAL OF

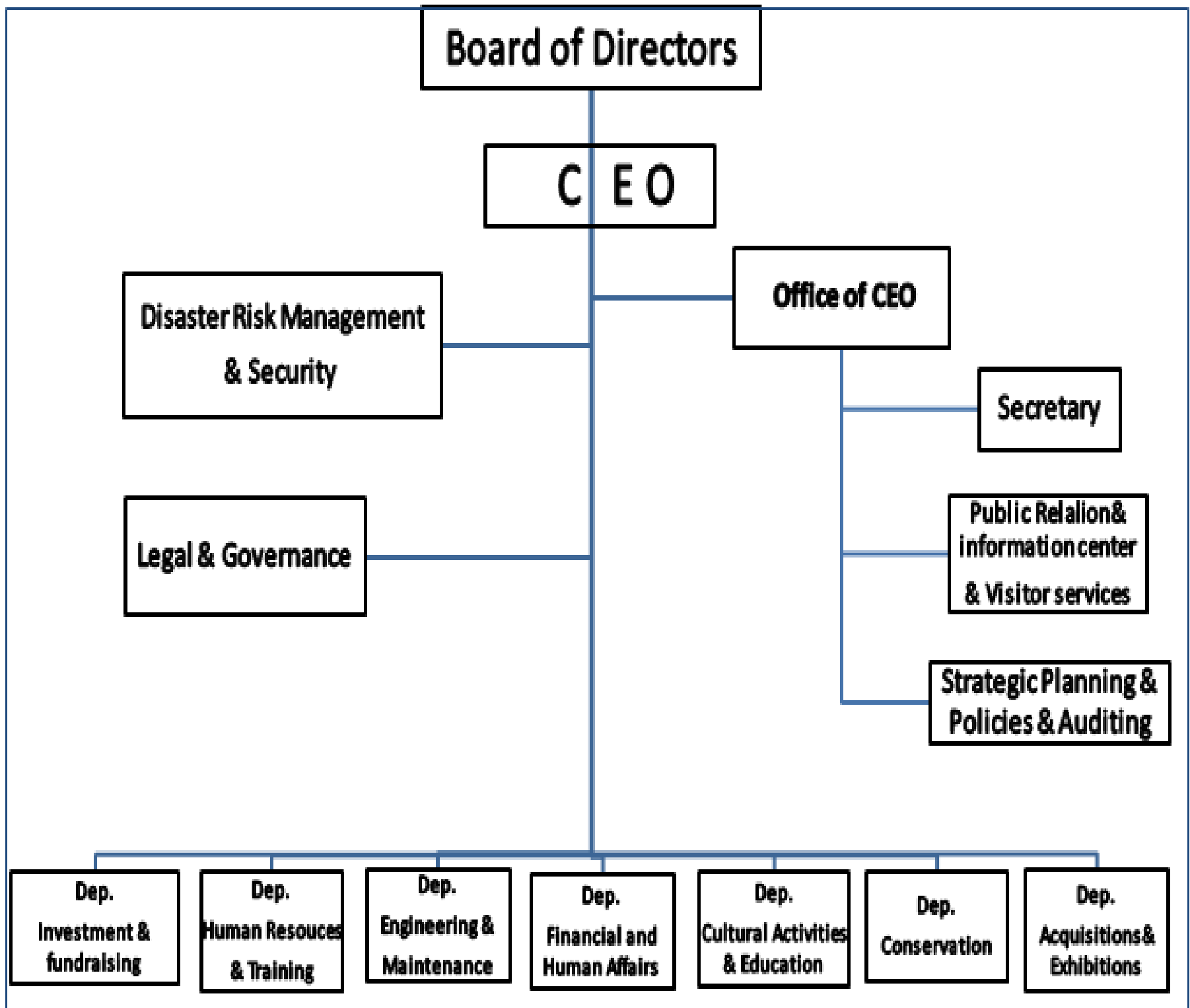

Fig. A proposal for an organizational chart of the Ethnographic museum

(Created by the researcher) 
INTERNATIONAL JOURNAL OF

MULTIDISCIPLINARY STUDIES ON MANAGEMENT, BUSINESS, AND ECONOMY

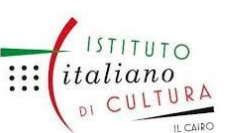

www.egyptfuture.org/ojs/ 